\title{
Bacteria-mediated aggregation of the marine phytoplankton Thalassiosira weissflogii and Nannochloropsis oceanica
}

\author{
Nhan-An T. $\operatorname{Tran}^{1,2}$ (D) Bojan Tamburic ${ }^{1,3,4}$ (D) $\cdot$ Christian R. Evenhuis $^{5}$ (D) $\cdot$ Justin R. Seymour ${ }^{1}$ (D)
}

Received: 5 June 2020 / Revised and accepted: 9 September 2020 / Published online: 30 September 2020

(C) The Author(s) 2020

\begin{abstract}
The ecological relationships between heterotrophic bacteria and marine phytoplankton are complex and multifaceted, and in some instances include the bacteria-mediated aggregation of phytoplankton cells. It is not known to what extent bacteria stimulate aggregation of marine phytoplankton, the variability in aggregation capacity across different bacterial taxa or the potential role of algogenic exopolymers in this process. Here we screened twenty bacterial isolates, spanning nine orders, for their capacity to stimulate aggregation of two marine phytoplankters, Thalassiosira weissflogii and Nannochloropsis oceanica. In addition to phytoplankton aggregation efficiency, the production of exopolymers was measured using Alcian Blue. Bacterial isolates from the Rhodobacterales, Flavobacteriales and Sphingomonadales orders stimulated the highest levels of cell aggregation in phytoplankton cultures. When co-cultured with bacteria, exopolymer concentration accounted for $34.1 \%$ of the aggregation observed in T. weissflogii and $27.7 \%$ of the aggregation observed in N. oceanica. Bacteria-mediated aggregation of phytoplankton has potentially important implications for mediating vertical carbon flux in the ocean and in extracting phytoplankton cells from suspension for biotechnological applications.
\end{abstract}

Keywords Environmental biotechnology $\cdot$ Microbial aggregation $\cdot$ Thalassiosira $\cdot$ Nannochloropsis $\cdot$ Microalgae-bacteria interactions

\section{Introduction}

The ecological interactions between marine phytoplankton and bacteria can vary from mutualistic to parasitic (Amin

Electronic supplementary material The online version of this article (https://doi.org/10.1007/s10811-020-02252-8) contains supplementary material, which is available to authorized users.

Nhan-An T. Tran

natt2@cam.ac.uk

1 Faculty of Science, University of Technology Sydney, Climate Change Cluster, NSW Sydney, Australia

2 Department of Plant Sciences, University of Cambridge, Cambridge, UK

3 Water Research Centre, School of Civil and Environmental Engineering, University of New South Wales Sydney, Sydney, NSW, Australia

4 Algae and Organic Matter (AOM) Laboratory, School of Chemical Engineering, University of New South Wales Sydney, Sydney, NSW, Australia

5 Faculty of Science, University of Technology Sydney, Infection, Immunity and Innovation Institute, NSW Sydney, Australia et al. 2012) and can strongly influence the physiology, metabolic activity, abundance and growth of both partners (Lee et al. 2000; Grossart and Simon 2007; Buchan et al. 2014). These interactions have been shown to promote microalgal growth (Seyedsayamdost et al. 2011), protect phytoplankton from pathogens (Geng and Belas 2010) or alternatively to inhibit microalgal growth (Mayali and Azam 2004), while at the same time governing the productivity and biogeochemistry of aquatic ecosystems (Cole 1982; Landa et al. 2016).

One of the ways that bacteria can influence phytoplankton is by increasing cell stickiness and consequently causing aggregation (Decho 1990; Heissenberger and Herndl 1994; Grossart et al. 2006b). Physical attachment of bacteria to phytoplankton cells has been shown to influence aggregation in several species (Rodolfi et al. 2003; Grossart et al. 2006b; Gärdes et al. 2010), which has potential significance for biogeochemical cycling in the ocean, because the aggregation of phytoplankton and subsequent sinking of organic matter in the form of marine snow increases the flux of organic carbon from surface waters to the deep ocean (Alldredge and Gotschalk 1989; Grossart and Ploug 2001; Grossart et al. 2006b), meaning these microscale interactions can have ecosystem-level implications (Amin et al. 2012, 2015; Landa et al. 2016). 
Bacterial mediation of phytoplankton aggregation not only is important in natural ecosystems but also has the potential to lead to biotechnological advances. The widespread commercialisation of microalgal bioproducts is hindered by inefficiencies in biomass harvesting, which impacts the cost of production (Milledge and Heaven 2013; Vandamme et al. 2013). Therefore, the application of phytoplankton-bacteria aggregates has been proposed as an effective preconcentration strategy, and it has been successfully applied in the water purification and wastewater treatment industries to extract biomass (de Godos et al. 2011). Given the emerging knowledge of phytoplankton-bacteria interactions within natural environments, a logical extension is to take advantage of these processes for biotechnological applications.

The impact of heterotrophic bacteria on phytoplankton aggregation rates can be highly variable. While bacteria may increase aggregation and the stability of aggregates (Heissenberger and Herndl 1994), attached bacteria may also reduce aggregation due to the hydrolysis of phytoplankton surface mucus (Grossart et al. 2006a, b). Moreover, the role of heterotrophic bacteria for phytoplankton aggregation can vary appreciably between phytoplankton species (Grossart et al. 2006b; Powell and Hill 2013) while the identity of the bacteria can also influence levels of aggregation (Kranck and Milligan 1988; Alldredge and Gotschalk 1989; Riebesell 1991; Alldredge et al. 1995; Gärdes et al. 2011; Nontembiso et al. 2011; Wang et al. 2012; Powell and Hill 2014).

Bacterial-induced phytoplankton aggregation is generally believed to be primarily governed by two key mechanisms: direct cell attachment and the secretion of aggregating polymers such as transparent exopolymer particles (TEP) (Grossart et al. 2006a). It is proposed that TEP constitute up to $40 \%$ of the POC pool in ocean surface waters, thus contributing to the marine carbon budget (Passow 2002a; Mari et al. 2017). Phytoplankton are significant producers of TEP, and diatoms have been shown to have particularly high rates of TEP production (Passow 2002a). Heterotrophic bacteria consume TEP (Grossart et al. 2006a), while on the other hand, their presence has also been shown to increase the production of TEP by phytoplankton (Decho 1990; Heissenberger and Herndl 1994; Grossart 1999; Gärdes et al. 2011), which may have important implications for the aggregation of, and enhanced sedimentation rates of senescent phytoplankton (Riebesell 1991).

The aim of the present study was to screen a range of bacteria from nine different taxonomic orders and determine their ability to aggregate two marine phytoplankton, Thalassiosira weissflogii and Nannochloropsis oceanica. Diatoms often dominate phytoplankton communities in coastal environments and the open ocean, supporting marine food webs through the organic carbon production; therefore, T. weissflogii was chosen for its ecological relevance (Armbrust 2009). Nannochloropsis oceanica was chosen for its biotechnological importance owing to its high oil content and widespread use as a feedstock in aquaculture (Chiu et al. 2009). Our goal was to develop a framework to understand phytoplankton-bacteria interactions in the context of microbial aggregation and TEP production and identify bacterial species of interest for biotechnological exploitation, while improving our understanding of the potential contribution of TEP to the marine carbon cycle.

\section{Materials and methods}

\section{Microorganisms and growth conditions}

Two marine phytoplankton species, Thalassiosira weissflogii (Strain CS-871, synonym CCMP-1336, Australian National Algae Culture Collection) and Nannochloropsis oceanica (Strain CS-179; Australian National Algae Culture Collection) were grown in filtered artificial seawater (salinity $32 \%$ ) enriched with F medium as described by Guillard and Ryther (1962). Stock cultures of xenic $N$. oceanica and T. weissflogii were maintained at $20{ }^{\circ} \mathrm{C}$ under a $12: 12 \mathrm{~h}$ light:dark cycle with fluorescent illumination at a photon flux density (PFD) of $40 \mu \mathrm{mol}$ photons $\mathrm{m}^{-2} \mathrm{~s}^{-1}$.

We selected 20 bacterial strains to screen for their capacity to aggregate $T$. weissflogii and $N$. oceanica (Table 1). These bacteria were chosen to represent a diverse range of taxonomic groups, and were isolated from a range of sources, including both natural environments and laboratory-maintained cultures. Marinobacter adhaerens HP 15 WT attaches to and aggregates T. weissflogii (Sonnenschein et al. 2012) and Bacillus megaterium has been shown to aggregate N. oceanica (Powell and Hill 2014); hence, both species were included as positive controls. All bacteria were grown in marine broth (BD Difco 279110, Becton Dickinson, USA) at 25 ${ }^{\circ} \mathrm{C}$, agitated at $180 \mathrm{rpm}$ and stored as glycerol stocks prior to experiments.

\section{Co-culture experiments}

Thalassiosira weissflogii and N. oceanica were grown for 6 days to mid-exponential phase, before being inoculated in 50 $\mathrm{mL}$ Tissue Culture Treated Flasks (Falcon, $25 \mathrm{~cm}^{2}$ culture area) in F medium at an initial cell density of $6-8 \times 10^{5}$ cells $\mathrm{mL}^{-1}$ and $1-2 \times 10^{6}$ cells $\mathrm{mL}^{-1}$, respectively. Bacteria were grown from glycerol stocks in marine broth overnight $\left(25^{\circ} \mathrm{C}, 180\right.$ $\mathrm{rpm})$. Bacterial cells were diluted with sterile $\mathrm{F}$ medium, and were added to the phytoplankton culture in a final concentration of $1.2-1.6 \times 10^{5}$ cells $\mathrm{mL}^{-1}$ for the $T$. weissflogii experiments and $2-4 \times 10^{5}$ cells $\mathrm{mL}^{-1}$ for the $N$. oceanica experiments in order to achieve an approximate final ratio of 1:5 bacteria:phytoplankton cells in $20 \mathrm{~mL}$. Phytoplankton and bacterial cell numbers were determined using a haemocytometer 
Table 1 Bacterial species used in this study, identified by class, order and genus, the site/source they were isolated from and accession number

\begin{tabular}{|c|c|c|c|c|c|c|}
\hline Bacteria ID (confirmed 16S) & $\begin{array}{l}\% \\
\text { ID }\end{array}$ & Class & Order & Genus & Site/source & $\begin{array}{l}\text { Accession } \\
\text { number }\end{array}$ \\
\hline Bacillus megaterium QMB1551 & 100 & Bacilli & Bacillales & Bacillus & $\begin{array}{l}\text { American Type Culture } \\
\text { Collection }\end{array}$ & CP1001983 \\
\hline Roseovarius litoreus GSW-M15 & 100 & Alphaproteobacteria & Rhodobacterales & Roseovarius & $\begin{array}{l}\text { Culture of Alexandrium } \\
\text { minutum CS324 }\end{array}$ & NR_109594 \\
\hline $\begin{array}{l}\text { Octadecabacter asciadiaceicola } \\
\text { RA1-3 }\end{array}$ & 99 & Alphaproteobacteria & Rhodobacterales & Octadecabacter & Port Hacking, NSW Australia & NR_147751 \\
\hline $\begin{array}{l}\text { Sulfitobacter mediterraneus } \\
\text { CH-B427 }\end{array}$ & 98 & Alphaproteobacteria & Rhodobacterales & Sulfitobacter & $\begin{array}{l}\text { Culture of Thalassiosira } \\
\text { pseudonana }\end{array}$ & NR_026472 \\
\hline Phaeobacter porticola $\mathrm{P} 97$ & 99 & Alphaproteobacteria & Rhodobacterales & Phaeobacter & Culture of Emiliania huxleyii & NR_157650 \\
\hline Shimia marina CL-TA03 & 100 & Alphaproteobacteria & Rhodobacterales & Shimia & Culture of Synechococcus & NR_043300 \\
\hline Erythrobacter citreus $\mathrm{RE} 35 \mathrm{~F} / 1$ & 100 & Alphaproteobacteria & Sphingomonadales & Erythrobacter & Culture of Emiliania huxleyii & NR_028741 \\
\hline Erythrobacter flavus SW-46 & 100 & Alphaproteobacteria & Sphingomonadales & Erythrobacter & $\begin{array}{l}\text { Culture of Thalassiosira } \\
\text { pseudonana }\end{array}$ & NR_025245 \\
\hline $\begin{array}{l}\text { Sphingorhabdus flavimaris } \\
\text { SW-151 }\end{array}$ & 99 & Alphaproteobacteria & Sphingomonadales & Sphingorhabdus & Culture of Synechococcus & NR_025814 \\
\hline $\begin{array}{l}\text { Marinobacter adhaerens HP15 } \\
\text { WT }\end{array}$ & 100 & Gammaproteobacteria & Alteromonadales & Marinobacter & Kaeppel et al. (2012) & NR_074765 \\
\hline $\begin{array}{l}\text { Alteromonas macleodii NBRC } \\
\quad 102226\end{array}$ & 100 & Gammaproteobacteria & Alteromonadales & Alteromonas & Port Hacking NSW Australia & NR_114053 \\
\hline Shewanella baltica 63 & 99 & Gammaproteobacteria & Alteromonadales & Shewanella & Iron Cove, NSW Australia & NR_025267 \\
\hline Acinetobacter bouvetii EU40 & 99 & Gammaproteobacteria & Pseudomonadales & Acinetobacter & $\begin{array}{l}\text { Botany Foreshores Beach, } \\
\text { NSW Australia }\end{array}$ & JF681285 \\
\hline Vibrio gigantis LGP 13 & 99 & Gammaproteobacteria & Vibrionales & Vibrio & Culture of Emiliania huxleyii & NR_044079 \\
\hline Maribacter lutimaris $\mathrm{KJ} 4$ & 99 & Flavobacteria & Flavobacteriales & Maribacter & $\begin{array}{l}\text { Culture of Alexandrium } \\
\text { minutum CS324 }\end{array}$ & NR_148860 \\
\hline Aquaticitalea lipolytica Ar-125 & 99 & Flavobacteria & Flavobacteriales & Aquaticitalea & Port Hacking, NSW Australia & NR_149769 \\
\hline Maribacter dokdonensis DSW-8 & 99 & Flavobacteria & Flavobacteriales & Maribacter & $\begin{array}{l}\text { Culture of Thalassiosira } \\
\text { pseudonana }\end{array}$ & NR_043294 \\
\hline $\begin{array}{l}\text { Winogradskyella poriferorum } \\
\text { UST030701-295 }\end{array}$ & 99 & Flavobacteria & Flavobacteriales & Winogradskyella & $\begin{array}{l}\text { Culture of Nannochloropsis } \\
\text { oceanica }\end{array}$ & NR_043230 \\
\hline $\begin{array}{l}\text { Roseivirga spongicola } \\
\text { UST030701-801 }\end{array}$ & 99 & Cytophagia & Cytophagales & Roseivirga & $\begin{array}{l}\text { Culture of Nannochloropsis } \\
\text { oceanica }\end{array}$ & NR_043531 \\
\hline Arcobacter venerupis F67-11 & 97 & Epsilonproteobacteria & Campylobacterales & Arcobacter & $\begin{array}{l}\text { Botany Foreshores Beach, } \\
\text { NSW Australia }\end{array}$ & NR_117569 \\
\hline
\end{tabular}

and flow cytometry, respectively, as described in Tran et al. (2017). Phytoplankton cultures without bacterial addition were used as negative controls. Co-culture flasks were shaken for $24 \mathrm{~h}$ at $70 \mathrm{rpm}$, and optical density (OD) at $750 \mathrm{~nm}$ and $\mathrm{pH}$ were measured immediately after inoculation $\left(t_{0}\right)$ and after $24 \mathrm{~h}$ $\left(t_{24}\right)$. $\mathrm{pH}$ was measured to confirm that aggregation was due to the presence of bacteria as opposed to autoflocculation at $\mathrm{pH}>$ 9.5 (Sukenik and Shelef 1984).

\section{Aggregation efficiency}

The aggregation efficiency of bacterial isolates co-cultured with $T$. weissflogii and $N$. oceanica was determined by measuring changes in OD (Vandamme et al. 2012). Briefly, $T$. weissflogii and $N$. oceanica co-cultures containing bacterial isolates, and control cultures containing no bacteria, were left to settle for $30 \mathrm{~min}$, before a 1-mL sample was taken from the middle of each culture flask, and the OD was measured at 750 $\mathrm{nm}$. The aggregation efficiency $\left(\eta_{\mathrm{a}}\right)$ was calculated according to the equation:

$\eta_{\mathrm{a}}=\frac{\mathrm{OD}_{\mathrm{t} 0}-\mathrm{OD}_{\mathrm{t} 24}}{\mathrm{OD}_{\mathrm{t} 0}} \times 100$

where $\mathrm{OD}_{\mathrm{t} 0}$ is the optical density of the culture immediately after inoculation with bacteria and $\mathrm{OD}_{\mathrm{t} 24}$ is the optical density of the same culture $24 \mathrm{~h}$ later. Three biological replicates were carried out for each phytoplankton-bacterium combination.

\section{TEP determination}

Transparent exopolymer particles (TEP) in the co-cultures were stained and quantified using the methodology of Passow and Alldredge (1995). Briefly, TEP were collected by filtering each sample through $0.2 \mu \mathrm{m}$ pore-size $25 \mathrm{~mm}$ 
polycarbonate Nucleopore filters (Whatman). The volume of sample necessary for each TEP analysis varied from 1 to $5 \mathrm{~mL}$ depending on the size of the aggregates and density of each culture, so as to avoid clogging the filter. After filtration, filters were stained for $3 \mathrm{~s}$ with $500 \mu \mathrm{L}$ of a $0.02 \%$ working solution of Alcian Blue (pre-filtered through a $0.2-\mu \mathrm{m}$ filter) in $0.06 \%$ acetic acid (8GX, Sigma). Alcian Blue binding was calibrated with Gum Xanthan (Sigma) according to the protocol described in Passow and Alldredge (1995). This colorimetric method measures all materials that adsorb Alcian Blue, which is directly related to the weight of a specific polysaccharide. The weight equivalent for the adsorption of Alcian Blue to TEP is given by using the reference exopolymer Gum Xanthan due to the heterogeneity of natural exopolymers (Engel and Passow 2001). Following staining, filters were rinsed twice with milliQ water to eliminate excess dye before storage at $-80^{\circ} \mathrm{C}$. The Alcian Blue stain was extracted by soaking the filters in $80 \%$ sulfuric acid for $2-3 \mathrm{~h}$ and analysed at $787 \mathrm{~nm}$. Empty filters stained with Alcian Blue were used as blanks. The concentration of TEP ([TEP]) was determined in units of Gum Xanthan equivalents per volume of sample filter $\left(\mu \mathrm{g} \mathrm{XG} \mathrm{L}{ }^{-1}\right)$.

\section{Epifluorescence and TEP imaging}

In order to visualise the proportion of bacteria attached to aggregated phytoplankton, and whether this coincided with a greater abundance of TEP, cultures were visualised by epifluorescence microscopy. Briefly, samples $(1 \mathrm{~mL})$ were fixed with glutaraldehyde (final conc. 1\%), stained with SYBR-Green-I (final conc. 1:10,000) and incubated for $15 \mathrm{~min}$ in the dark. Stained samples were filtered onto $0.2 \mu \mathrm{m}$ pore-size $25 \mathrm{~mm}$ polycarbonate Nucleopore filters (Whatman), stained with Alcian Blue as described above, and washed with $2 \mathrm{~mL}$ milliQ water to eliminate excess dye. Samples were imaged at $\times 40$ magnification for $T$. weissflogii and $\times 100$ magnification for $N$. oceanica using an epifluorescence microscope (Nikon Eclipse Ni-E equipped with a DS-Qi2 monochrome and DS-Fi2 colour camera), with cells visualised using 488 LP (excitation $460 \times 490 \mathrm{~nm}$ and emission $>500 \mathrm{~nm}$ ) and mCherry (excitation $535 \times 555 \mathrm{~nm}$ and emission $>595 \mathrm{~nm}$ ) filters for SYBR-Green-I stained bacteria and phytoplankton autofluorescence, respectively. Alcian Blue staining of TEP was visualised by brightfield microscopy. Image processing involved inverting the brightfield images in order to merge it with the fluorescence channels, and false colours were used to improve contrast.

\section{Statistical analyses}

For both phytoplankton, aggregation efficiency and TEP concentration, data were compared between the control and each bacterial species by permutational analysis of variance
(PERMANOVA) using the PRIMER v6 and PERMANOVA+ software and Euclidean distance. PERMANOVA Monte Carlo pairwise comparisons, corresponding to t-statistics, were performed where significant differences were observed. To determine the influence of TEP concentration on aggregation efficiency, a regression analysis was performed on all biological replicates for both phytoplankton.

\section{Results}

\section{Aggregation efficiency and TEP production}

Twenty different species of bacteria were screened for their ability to stimulate aggregation of the marine phytoplankton $T$. weissflogii and $N$. oceanica. Significant $(p<0.05)$ levels of aggregation of $T$. weissflogii were observed following the addition of 16 of these bacterial strains, while in $N$. oceanica, 17 bacterial strains caused aggregation. In the negative control cultures, where there was no addition of bacteria, negative aggregation efficiencies were observed: $-15.1 \pm 4.3 \%$ for T. weissflogii cultures and $-4.1 \pm 2.0 \%$ for $N$. oceanica cultures. Negative aggregation efficiency implies net phytoplankton culture growth, with the culture becoming more turbid during the experimental period. The degree of aggregation varied significantly $(p<0.05)$ across bacterial isolates, and the Sphingomonadales and Erythrobacter citreus caused the highest levels of aggregation of both T. weissflogii (Fig. 1a) and $N$. oceanica cells (Fig. 1b). When co-cultured with E. citreus, the aggregation efficiency within $T$. weissflogii cultures was $78.5 \pm 3.8 \%(p=0.002)$ and it was $77.7 \pm 1.8 \%(p=$ 0.001 ) in $N$. oceanica cultures. A bacterium of the same genus, Erythrobacter flavus, was also responsible for stimulating high levels of aggregation of cells in co-culture with T. weissflogii $(60.4 \pm 1.7 \% ; p=0.001)$ and $N$. oceanica $(70.8 \pm 1.9 \%, p=0.001)$. The Flavobacteriales were another taxonomic group showing high levels of aggregation of phytoplankton cells. In co-culture, Maribacter lutimaris aggregated $58.4 \pm 1.7 \%(p=0.002)$ of $T$. weissflogii cells and $72.8 \pm$ $2.5 \%$ ( $p=0.002)$ of $N$. oceanica cells. Two members of the Rhodobacterales, Octadecabacter asciadiaceicola and Roseovarius litoreus, were also capable of stimulating high levels of aggregation. In $T$. weissflogii cultures, O. asciadiaceicola aggregated $62.7 \pm 2.0 \%(p=0.001)$ of cells, while in $N$. oceanica cultures, $R$. litoreus aggregated $61.2 \pm 2.0 \%(p=0.001)$ of cells. The efficiency of bacteriamediated aggregation was compared against high-pH aggregation induced by $\mathrm{NaOH}$ addition (Vandamme et al. 2012). Notably, the bacteria-mediated aggregation efficiency of E. citreus was only $15.4 \%$ lower than high-pH aggregation efficiency in T. weissflogii cultures $(93.9 \pm 0.2 \%)$, and $9.4 \%$ lower in $N$. oceanica cultures $(87.1 \pm 1.0 \%)$. 


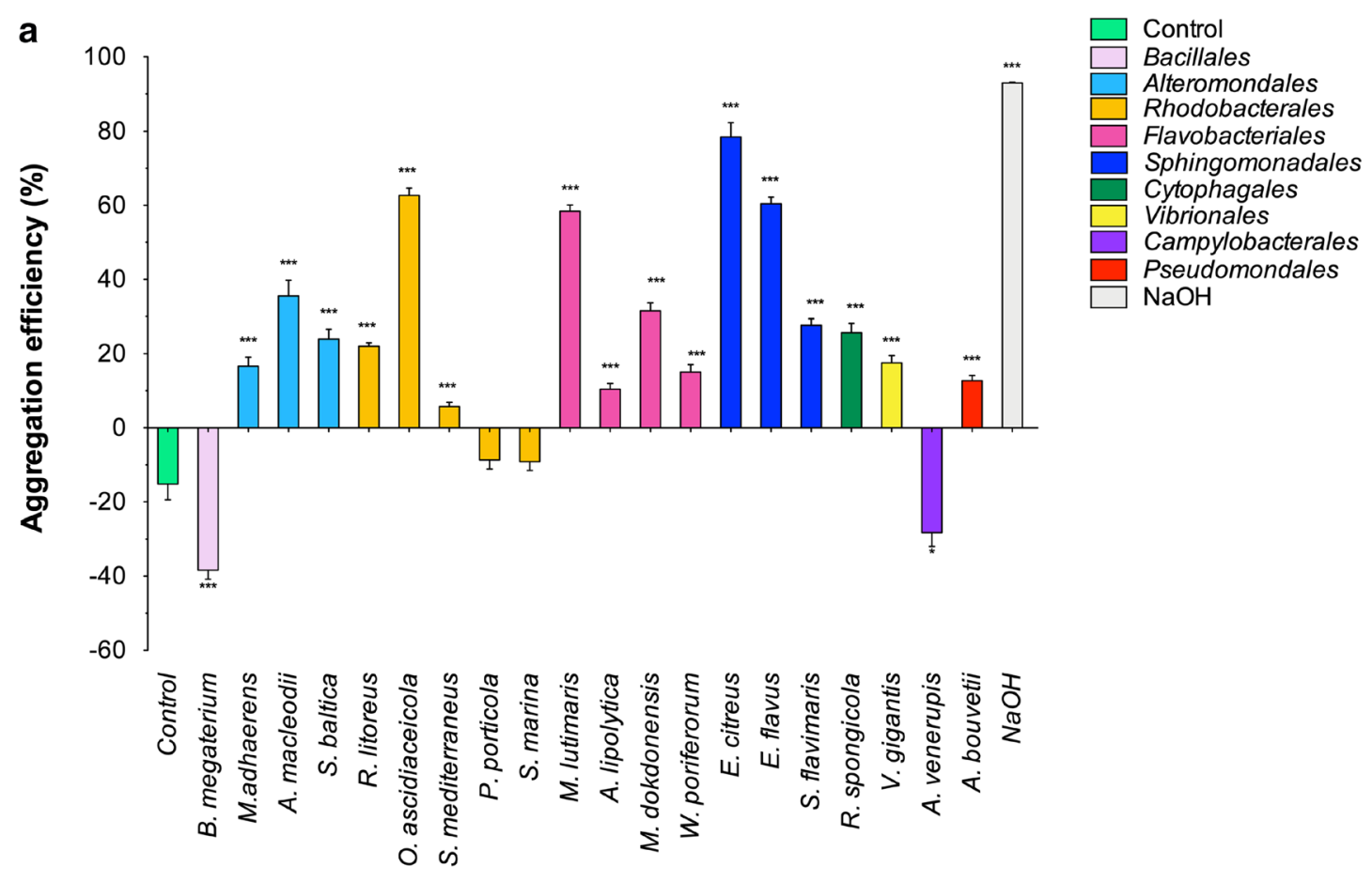

Bacteria Species by Order

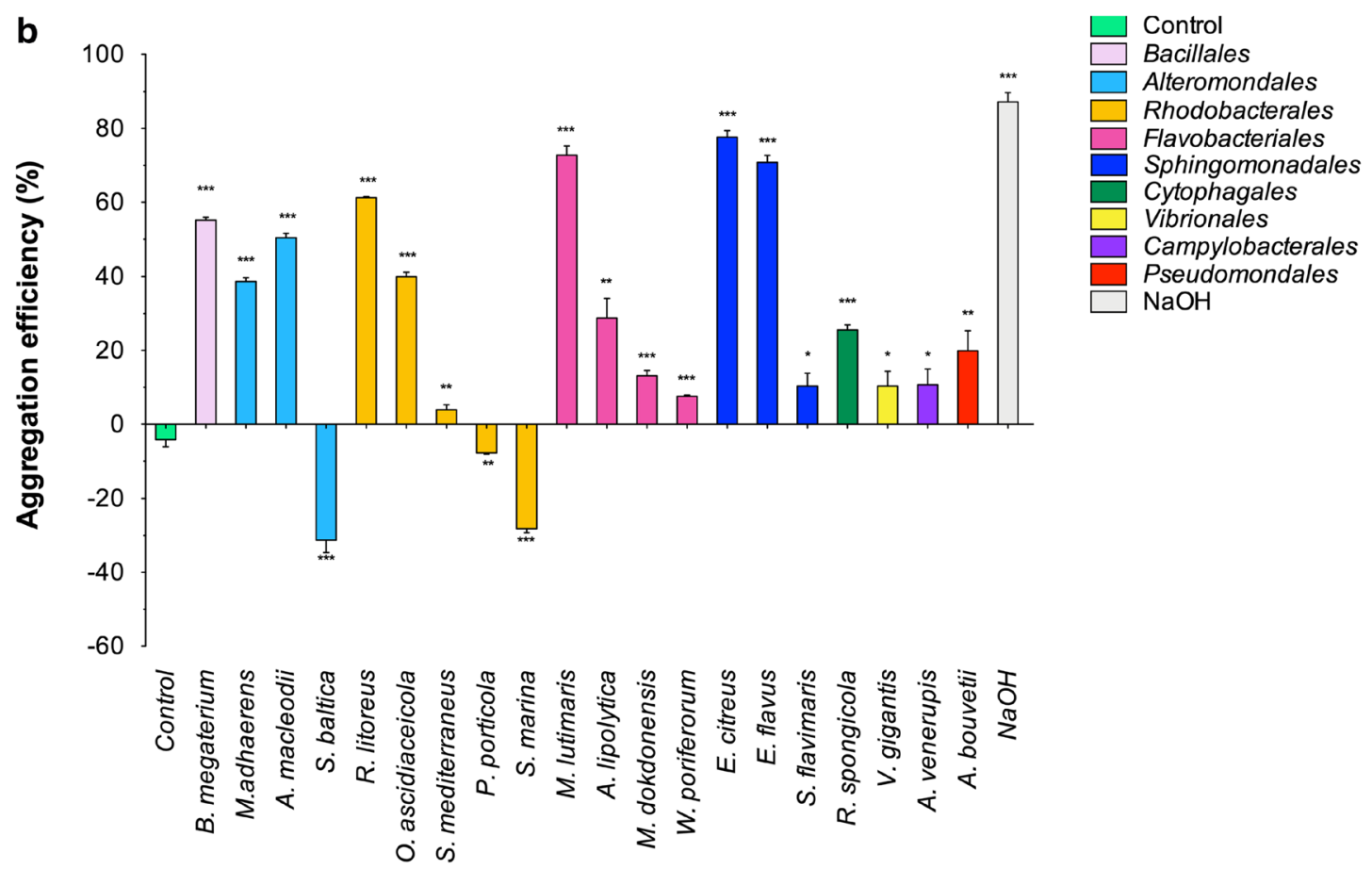

Bacteria Species by Order

Fig. 1 Aggregation efficiency (\%) within phytoplankton cultures after $24 \mathrm{~h}$ of co-incubation with different bacterial isolates a $T$. weissflogii. b $N$. oceanica. No bacteria were added to the negative control. High-pH aggregation was used as a positive control. Colours are representative of different bacterial orders. Mean $\pm \operatorname{SEM}(n=3)$. Significance level of $\alpha<$ 0.05 was set, $*<0.05, * *<0.01, * * *<0.001$. Negative aggregation efficiency implies net phytoplankton culture growth 
Interestingly, the Bacillales bacterium B. megaterium stimulated significant levels of aggregation in $N$. oceanica cultures $(55.2 \pm 0.8 \%, p=0.001)$, but did not cause aggregation of T. weissflogii $(-38.3 \pm 2.5 \%, p=0.003)$. The same pattern was also observed for the Campylobacterales bacterium Arcobacter venerupis, which stimulated aggregation in $N$. oceanica cultures $(10.7 \pm 4.3 \%, p=0.023)$, but not in T. weissflogii cultures $(-28.2 \pm 3.7 \%, p=0.04)$. In contrast, one of the Alteromonadales isolates, Shewanella baltica, caused aggregation of $T$. weissflogii $(24.0 \pm 2.6 \%, p=$ $0.001)$, but not of $N$. oceanica $(-31.2 \pm 3.4 \%, p=0.002)$. Two of the Rhodobacterales isolates, namely Phobacter porticola and Shimia marina, led to negative aggregation efficiency in both $T$. weissflogii $(-8.7 \pm 2.4 \%, p>0.05 ;-9.1 \pm$ $2.4 \%, p>0.05)$ and $N$. oceanica $(-7.7 \pm 0.4 \%, p=0.008$; $28.2 \pm 1.1 \%, p=0.001$ ).

Overall, the three highest aggregating bacterial species of $T$. weissflogii or $N$. oceanica also generated some of the greatest concentrations of TEP in co-culture with these phytoplankton. During the co-culture experiments, concentrations of TEP varied significantly among bacterial species. In T. weissflogii, TEP concentrations ranged between 189 and $11,258 \mu \mathrm{g} \mathrm{XG} \mathrm{L}^{-1}$ (Fig. 2a), with the highest concentrations produced by co-cultures containing Maribacter lutimaris $\left(11,258 \pm 1122 \mu \mathrm{g} \mathrm{XG} \mathrm{L}{ }^{-1} ; p=0.001\right)$ and O. asciadiaceicola $\left(10,063 \pm 440 \mu \mathrm{g} \mathrm{XG} \mathrm{L}{ }^{-1} ; p=0.001\right)$. These values were significantly different to the TEP concentration of the control culture $\left(3339 \pm 379 \mu \mathrm{g} \mathrm{XG} \mathrm{L}^{-1}\right)$.

In $N$. oceanica, TEP concentrations ranged between -1551 and $8910 \mu \mathrm{g} \mathrm{XG} \mathrm{L}^{-1}$ (Fig. 2b). When co-cultured with bacteria, the highest TEP concentrations were measured with Acinetobacter bouvetii $\left(8910 \pm 454 \mu \mathrm{g} \mathrm{XG} \mathrm{L}{ }^{-1} ; p=0.001\right)$ and Erythrobacter citreus $\left(8503 \pm 986 \mu \mathrm{g} \mathrm{XG} \mathrm{L}{ }^{-1} ; p=0.001\right)$, with significantly higher levels of TEP production than in the control $\left(2764 \pm 5 \mu \mathrm{g} \mathrm{XG} \mathrm{L}^{-1}\right)$ in both cases.

Bacteria of the order Rhodobacterales, Sphingomonadales and Flavobacteriales were some of the highest aggregating species in co-culture, and it is notable that co-culture with these isolates also corresponded with the greatest amount of TEP production. A regression analysis was performed to assess the impact of TEP concentration on aggregation efficiency. A significant positive relationship was observed between TEP concentration and aggregation efficiency for both $T$. weissflogii and $N$. oceanica when co-cultured with bacteria. TEP concentration accounted for $34.1 \%(p<0.0001)$ of the aggregation observed in T. weissflogii (Fig. 3a) and 27.7\% $(p<0.0001)$ of the aggregation observed in $N$. oceanica (Fig. $3 \mathrm{~b}$ ).

\section{Microscopic characterisation of phytoplankton aggregates and TEP}

Microscopic visualisation of co-cultures following the $24 \mathrm{~h}$ incubation period indicated that TEP was present in all cultures. Similar amounts of TEP were present in the control cultures of $T$. weissflogii (Fig. 4a) and in non-aggregating cocultures with $S$. marina (Fig. $4 b$ ). In contrast, when $T$. weissflogii was in co-culture with E. citreus, Alcian Bluestainable material formed a significant component of aggregates (Fig. 4c). Similar results were observed in the same three conditions of $N$. oceanica, with minimal TEP in the control cultures (Fig. 4d) and in non-aggregating co-cultures of $N$. oceanica with S. marina (Fig. 4e) and greater amounts of Alcian Blue-staining material in aggregates if $N$. oceanica in co-culture with E. citreus (Fig. 4f). Within aggregates, there was a clear pattern of phytoplankton and bacterial cells surrounded by a matrix of TEP.

\section{Discussion}

There is evidence that microscale interactions between heterotrophic bacteria and phytoplankton in the ocean might play a role in facilitating aggregation of phytoplankton biomass (Gärdes et al. 2011; Sonnenschein et al. 2012). If widespread, this process will have a significant impact on ocean biogeochemistry by potentially contributing to enhanced sedimentation of particulate organic matter (Engel 2004). In addition, exploiting the relationship between bacteria and phytoplankton in co-cultures could lead to novel aggregation strategies that improve phytoplankton harvesting efficiency for biotechnological applications (Ummalyma et al. 2017). This study compared the aggregation efficiency of a diverse library of twenty marine bacterial isolates, derived from laboratory phytoplankton cultures and isolated from the natural environment, on two marine phytoplankton, $T$. weissflogii and $N$. oceanica, which were chosen due to their ecological and biotechnological relevance.

\section{Key bacterial phylogenetic groups implicated in aggregation and TEP production}

A range of bacteria, spanning nine different taxonomic orders, stimulated aggregation of $T$. weissflogii and $N$. oceanica. Of these, only three bacteria isolates had entirely different effects on the two different phytoplankton species. Specifically, $S$. baltica stimulated aggregation of $T$. weissflogii but not $N$. oceanica, while B. megaterium and A. venerupis caused aggregation of $N$. oceanica but not $T$. weissflogii. These bacteria comprise three different taxonomic orders, Alteromonadales, Bacillales and Campylobacterales, respectively, which is indicative of species-specific effects on aggregation. Evidence for exopolymer production by $S$. baltica and B. megaterium may have contributed to the observed aggregation (Neal et al. 2007; Powell and Hill 2014); however, our understanding remains limited as little evidence exists for the ability of these bacteria to aggregate phytoplankton. However, 


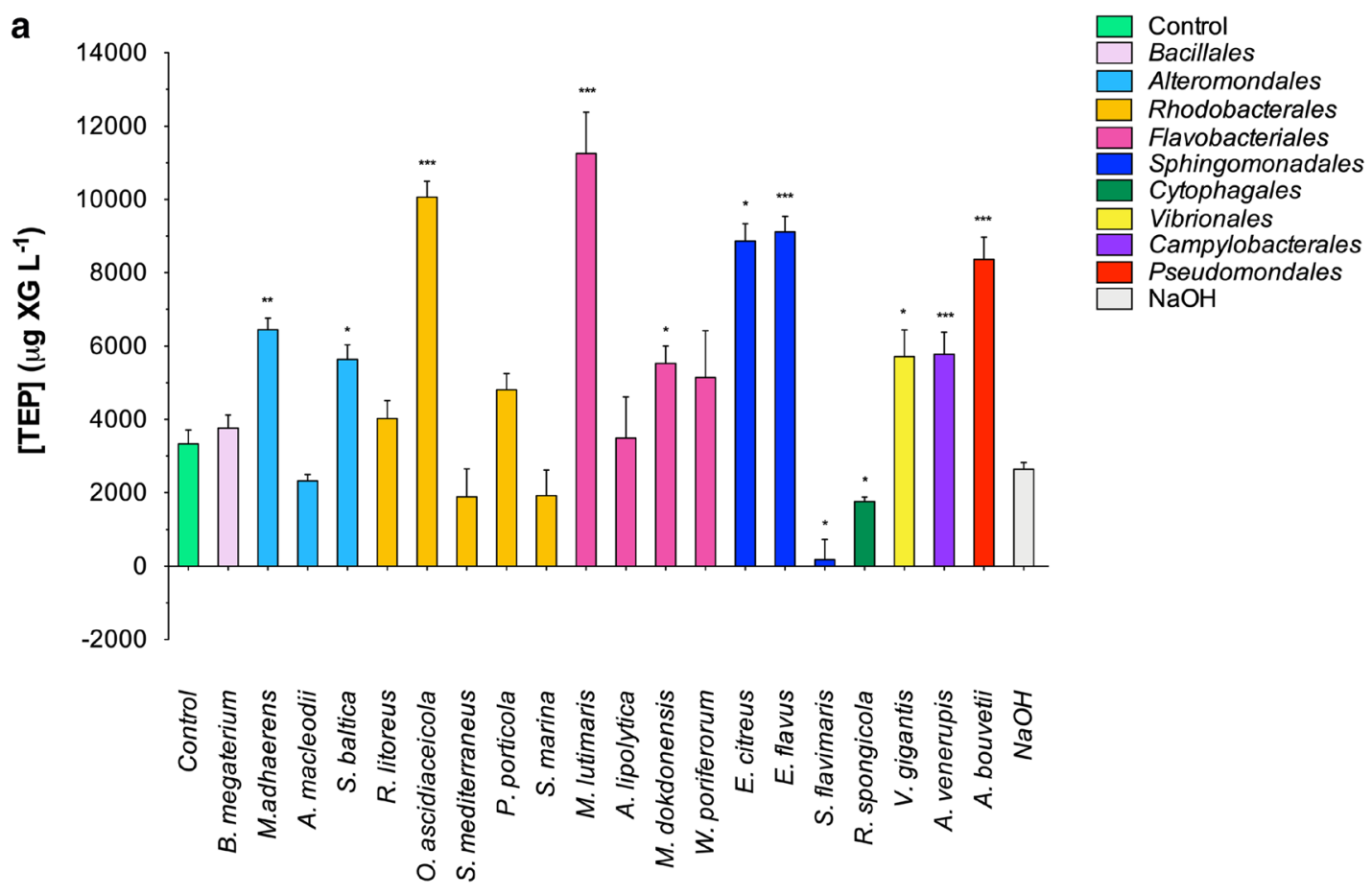

Bacteria Species by Order

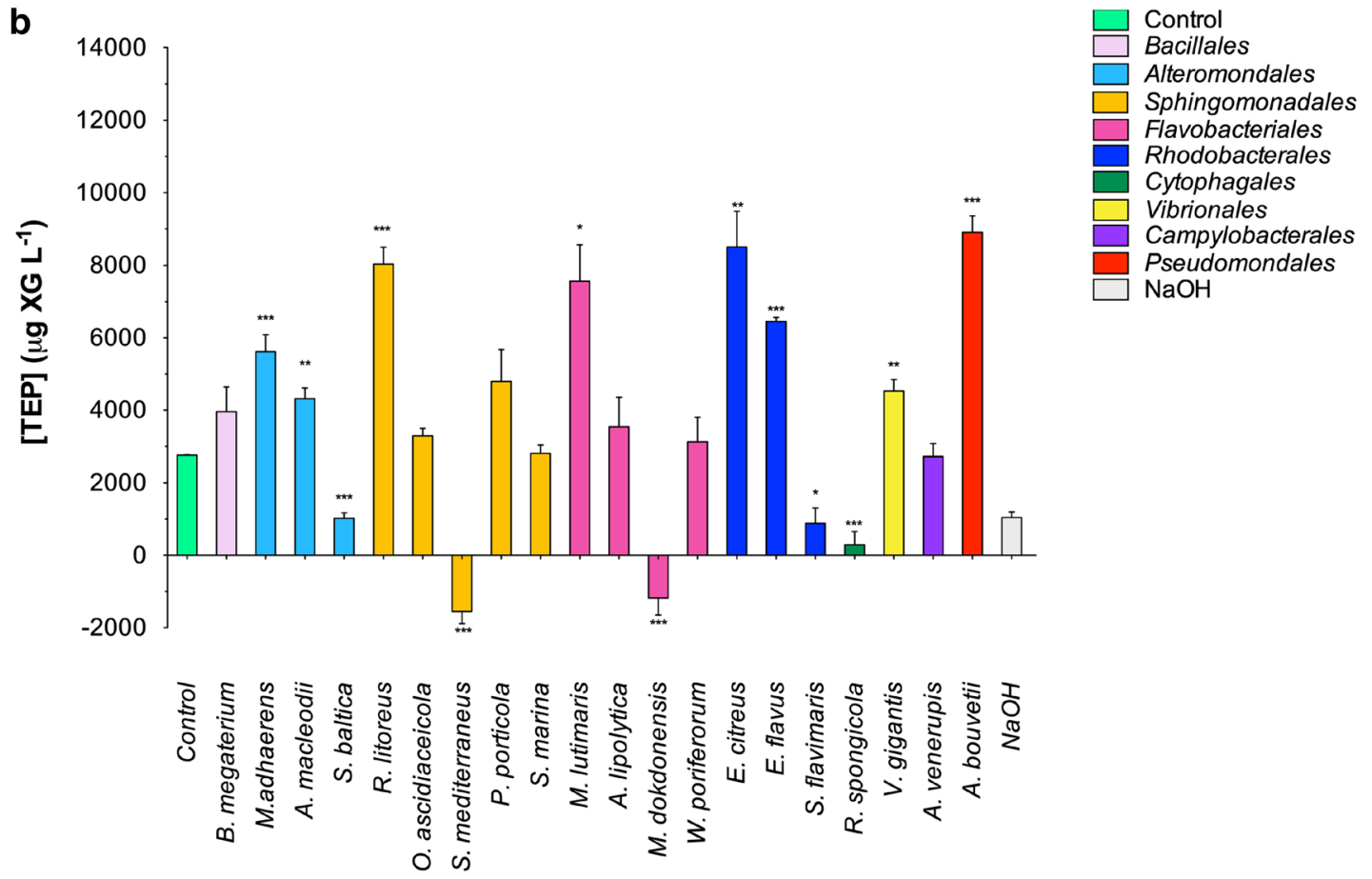

\section{Bacteria Species by Order}

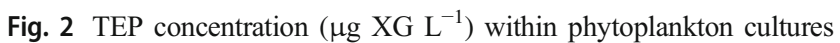
after $24 \mathrm{~h}$ of co-incubation with bacterial isolates a $T$. weissflogii. b $N$. oceanica. No bacteria were added to the negative control. High-pH aggregation was used as a positive control. Colours are representative of different bacterial orders. Mean $\pm \operatorname{SEM}(n=3)$. Significance level of $\alpha<$ 0.05 was set, $*<0.05, * *<0.01, * * *<0.001$. Negative TEP concentration implies net TEP consumption by bacteria 


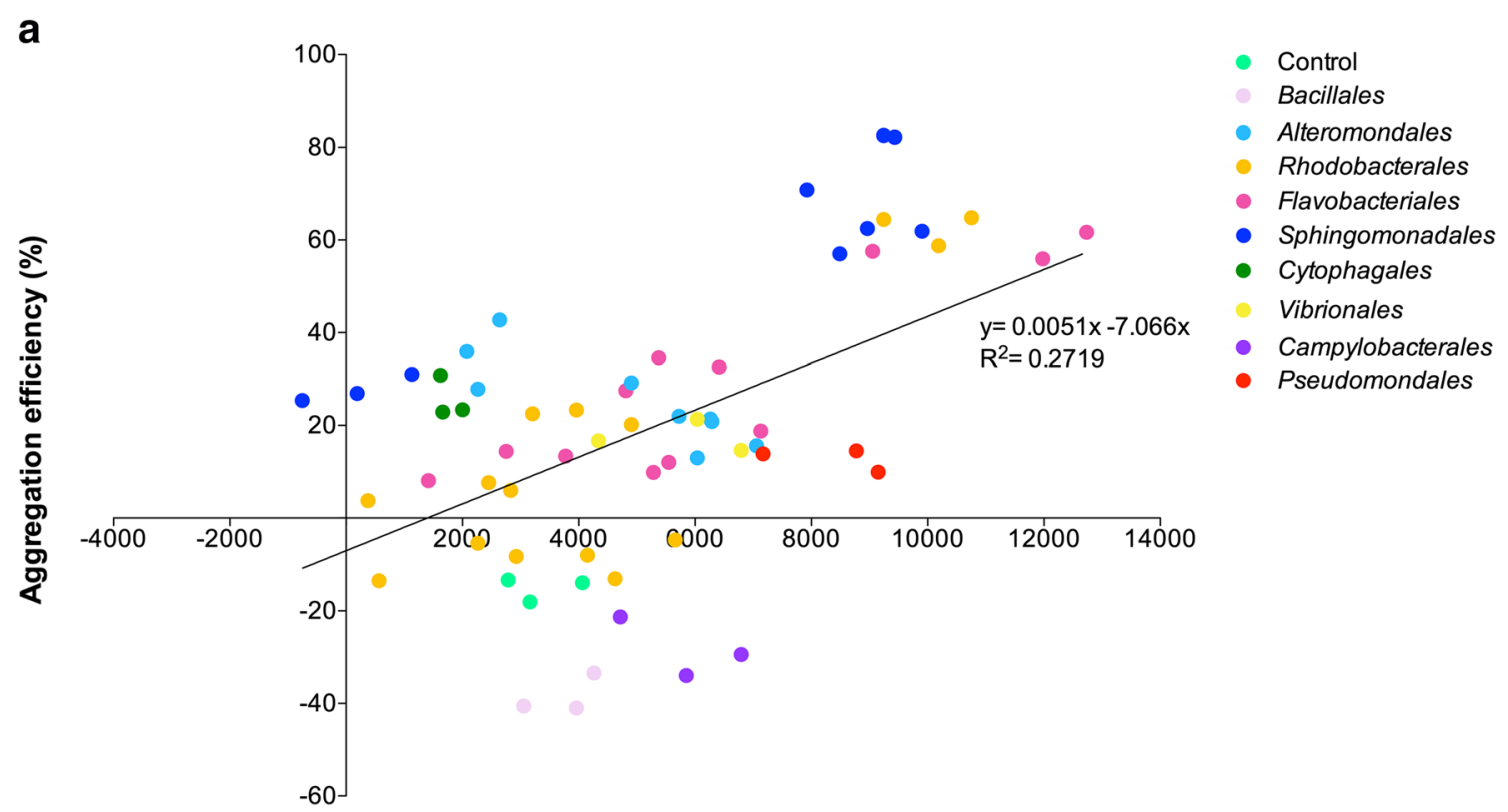

TEP concentration $\left(\mu \mathrm{g} X \mathrm{X} \mathrm{L}^{-1}\right)$

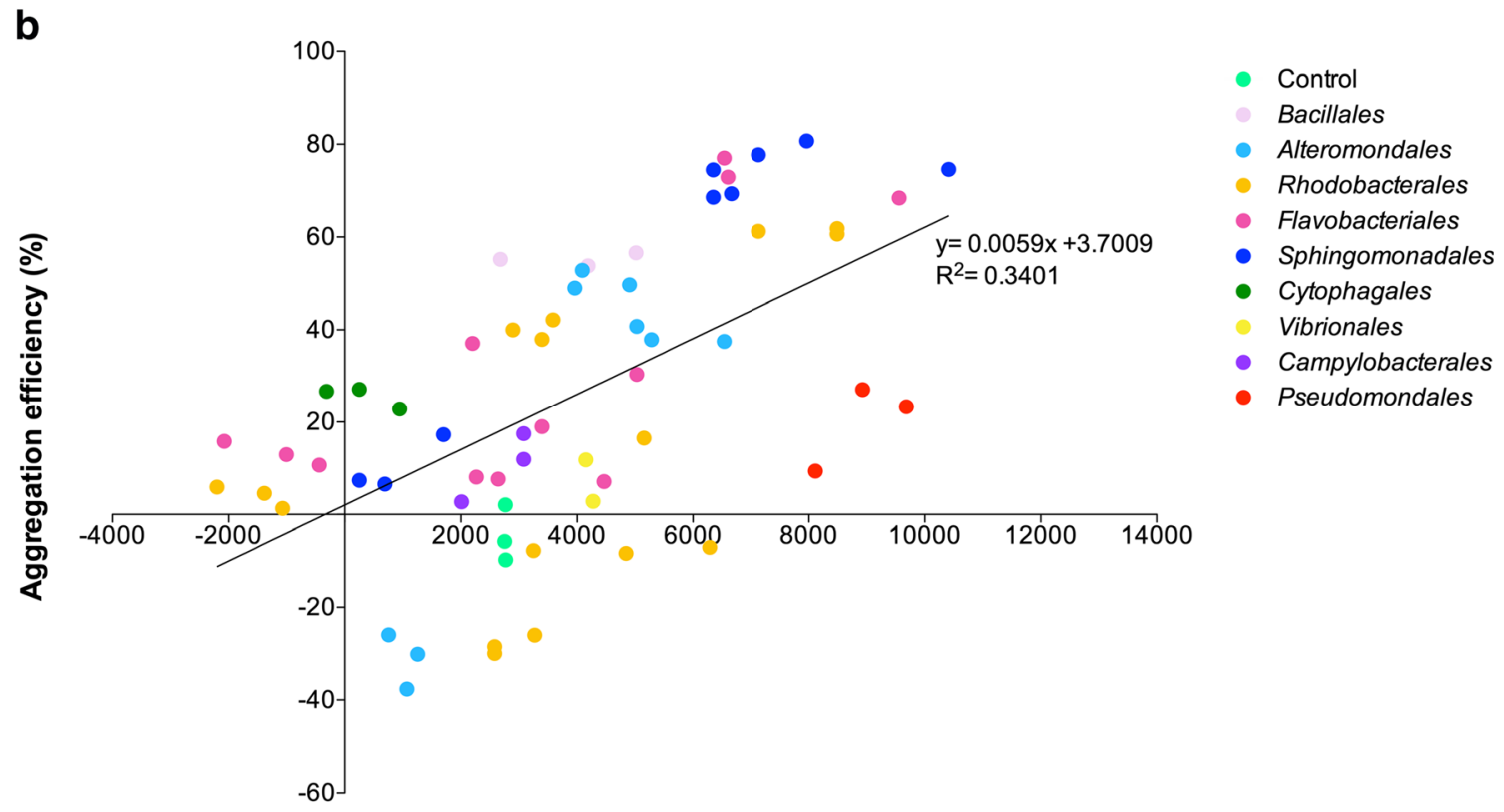

TEP concentration ( $\left.\mu \mathrm{g} X \mathrm{X} \mathrm{L}^{-1}\right)$

Fig. 3 The relationship between TEP concentration $\left(\mu \mathrm{gG} \mathrm{L}^{-1}\right)$ and aggregation efficiency (\%) for a T. weissflogii and $\mathbf{b} N$. oceanica. Each dot represents one biological replicate with three biological replicates for

across the other 17 bacterial species, remarkably generalisable effects were observed across the two phytoplankton species.

When co-cultured with either T. weissflogii or $N$. oceanica, the bacteria that caused the highest levels of aggregation belonged to the Sphingomonadales and Rhodobacterales (class Alphaproteobacteria) and Flavobacteriales (phylum Bacteroidetes) orders. This result is consistent with previous each bacterial isolate, and colours are representative of different orders of bacteria

observations that bacteria of the Alphaproteobacteria, Gammaproteobacteria and Bacteroidetes groups are often associated with marine aggregates (Amin et al. 2012; Teeling et al. 2012; Milici et al. 2017) and they are regular members of phytoplankton microbiomes (Goecke et al. 2013; Krohn-Molt et al. 2013). Gärdes et al. (2011) demonstrated that certain bacteria in the Gammaproteobacteria, Flavobacteria and 
Firmicutes groups were able to induce aggregation of $T$. weissflogii, with physical attachment of the bacterial cells to the diatom shown to be necessary. Similarly, other studies have identified members of the Firmicutes, including Bacillus sp. (Zheng et al. 2012; Powell and Hill 2013) and Solibacillus silvestris (Wan et al. 2013), and a member of the Pseudomonadales (Wang et al. 2012) as catalysts for aggregation in $N$. oceanica. Our experiments expand upon these previous studies by providing evidence of phytoplanktonaggregation ability among a broad diversity of bacterial species.

The highly variable levels of aggregation efficiency caused by bacteria within the same order were perhaps surprising. Among the Rhodobacterales, $R$. litoreus and $O$. asciadiaceicola caused high levels of aggregation of both $N$. oceanica and $T$. weissflogii, while $P$. porticola and $S$. marina did not stimulate any notable aggregation, suggesting that the aggregation phenotype is not conserved at the order level. The significantly negative aggregation efficiency in P. porticola and S. marina co-cultures was in fact indicative of an increase in suspended phytoplankton biomass, suggesting that these bacteria led to an enhancement of growth of the phytoplankton relative to control conditions. This is consistent with observations that, while generally exhibiting ecological associations with phytoplankton, members of this group can have vastly different effects on phytoplankton growth. For instance, some members of the Rhodobacterales are the dominant providers of $B_{12}$ (cobalamin) to phytoplankton (SañudoWilhelmy et al. 2014), where, for example, Ruegeria pomeroyi substantially restored the growth rate of $\mathrm{B}_{12}$ limited Thalassiosira pseudonana (Durham et al. 2015). Additionally, Sulfitobacter strains, also within the Rhodobacterales, have been shown to enhance the growth rate of $T$. pseudonana by 18-35\%, but closely related strains of Phaeobacter had no effect on diatom growth (Amin et al. 2015). The variation observed among phytoplanktonbacteria dynamics within the same order highlights the complexity of microbial interactions and might be explained by differences in the exchanges of signalling molecules between the phytoplankton and bacteria (Amin et al. 2012).

Of the bacterial isolates from within the Sphingomonadales order examined here, both strains of Erythrobacter were responsible for invoking the highest levels of aggregation of $N$. oceanica, with similar effects observed on $T$. weissflogii. Previous studies have shown that members of Sphingomonadales are known producers of TEP (Ashtaputre and Shah 1995; Yamazaki et al. 1996; Cydzik-Kwiatkowska 2015), are abundant members of particle-attached bacterial communities during phytoplankton blooms (Li et al. 2011; Louati et al. 2015) and represent a dominant group in aquatic biofilms (Niederdorfer et al. 2016) and within flocs in activated sludge (Neef et al. 1999). Given that both bacteria from the Erythrobacter genus induced high levels of $N$. oceanica aggregation and produced some of the highest amounts of TEP, we propose that their role in aggregate formation may have important ecological and biotechnological implications.

Members of the Flavobacteriales have been widely demonstrated to often have a preference for attached lifestyles (Sapp et al. 2007; Zheng et al. 2017) and to occur in association with phytoplankton (Buchan et al. 2014). All of the isolates in the order Flavobacteriales caused significantly high aggregation efficiency compared with the control culture. Furthermore, M. lutimaris produced a significant amount of TEP when in co-culture with $T$. weissflogii and $N$. oceanica. In contrast, despite causing aggregation, Aquaticitalea lipolytica, Maribacter dokdonensis and Winogradskyella poriferorum did not produce significant TEP when cocultured with either $T$. weissflogii or $N$. oceanica. Members of the Cytophaga-Flavobacterium-Bacteroides phylum seem to play an important role in the degradation of algal blooms, with high levels of attachment to phytoplankton cells during bloom decline observed (Fernández-Gómez et al. 2013). As dominant colonisers of marine snow (Bidle and Azam 2001; Simon et al. 2002), all Flavobacteriales appear to be able to hydrolyse polymers and complex polysaccharides (Reichenbach 1992). In fact, when co-cultured with $N$. oceanica, the presence of $M$. dokdonensis led to negative TEP values, suggesting bacterial consumption of TEP produced under baseline conditions. As well-known colonisers and degraders of phytoplankton-derived TEP (Teeling et al. 2012; Buchan et al. 2014; Milici et al. 2017), this species of Flavobacteriales may therefore have initiated aggregation of the phytoplankton in order to consume the resulting TEP.

In general, the three key phylogenetic groups of bacteria implicated in aggregation, namely Sphingomonadales, Flavobacteriales and Rhodobacterales, are major groups in the class Alphaproteobacteria and Flavobacteria, which are known degraders of dissolved and particulate organic matter. In this study, these bacteria have been shown to effectively aggregate $T$. weissflogii and $N$. oceanica, as well as stimulate the production of significant amounts of TEP, though whether TEP production originates from phytoplankton or bacteria remains unclear. All of these groups of bacteria have elsewhere been shown to be associated with phytoplankton (Schäfer et al. 2002; Sapp et al. 2007; Goecke et al. 2013; Ramanan et al. 2015) and to exhibit different roles (from symbiotic to parasitic) in bacteriaphytoplankton associations (Mayali and Azam 2004; Seyedsayamdost et al. 2011; Amin et al. 2015). The results of this study demonstrate that members of these groups also play a role in the way that phytoplankton biomass is aggregated and potentially subsequently transferred to depth. Therefore, we propose that members of these groups likely play important roles in ocean carbon cycling, while also having great potential for contributing to biotechnological harvesting of algal biomass. 

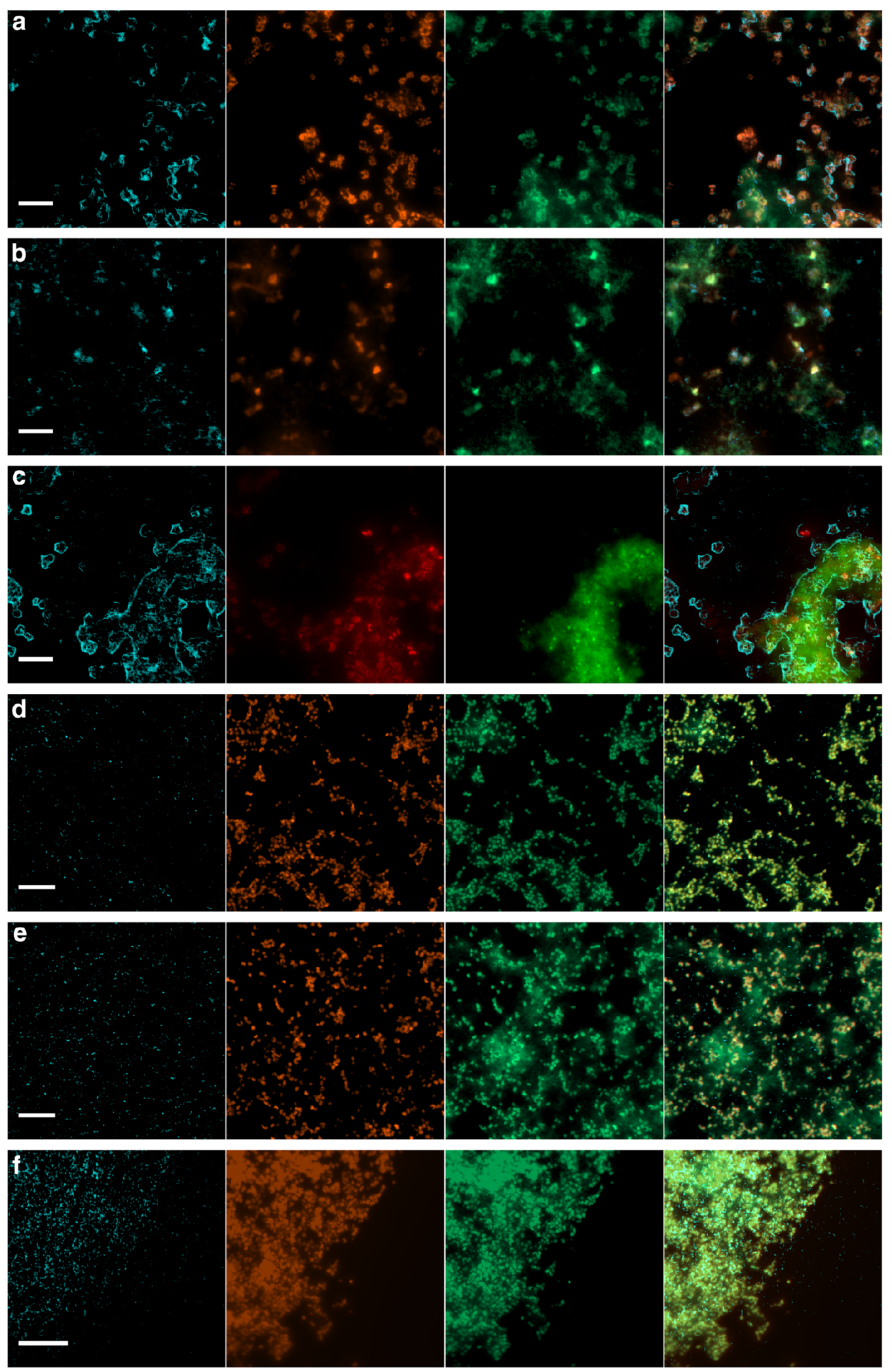

Fig. 4 Inverted brightfield and epifluorescence images of $T$. weissflogii in a the control culture, b non-aggregating co-culture with $S$. marina and c aggregating co-culture with E. citreus; and of $N$. oceanica in d the control culture, e non-aggregating co-culture with $S$. marina and $\mathbf{f}$ aggregating co-culture of E. citreus. The mosaic from the left to right represents transparent exopolymer particles (TEP, blue) stained with Alcian Blue, chlorophyll autofluorescence of $N$. oceanica and $T$. weissflogii cells (red), bacterial and algal nuclei stained with SYBR-Green (green) and an overlay of all three channels. Scale bar $=10 \mu \mathrm{m}$ 


\section{Contribution of TEP to aggregation}

The influence of TEP in phytoplankton aggregation has been demonstrated in previous studies (Decho 1990; Heissenberger and Herndl 1994). For example, bacterial colonisation of marine diatoms coincides with the production of large amounts of exopolymer substances, which increase phytoplankton cell stickiness and consequently aggregation (Smetacek 1985). From the forty bacteria-phytoplankton co-cultures tested in this study, TEP production was found to account for $34.1 \%$ and $27.7 \%$ of the aggregation observed in T. weissflogii and $N$. oceanica, respectively. It however remains unclear whether TEP was produced by the bacteria in the presence of the phytoplankton or whether the bacteria induce TEP production in the phytoplankton, and current methods make it impossible to distinguish between the sources of TEP production. Overall, there was a positive relationship between TEP concentration and aggregation efficiency. This was supported by epifluorescence microscopy, which revealed that, in cases where aggregation occurred, both bacteria and phytoplankton cells became embedded in a matrix of TEP.

Overall, higher levels of TEP production were measured in $T$. weissflogii than $N$. oceanica co-cultures, suggesting that the phytoplankton cell plays a key role in determining TEP production during interactions with bacteria. This is consistent with previous studies that have observed significant differences in TEP production between different phytoplankton species in cultures (Passow and Alldredge 1994) and in the environment (Grossart and Simon 1997, Grossart 1998). A study by Kiørboe and Hansen (1993) investigated the stickiness of five diatom species and two flagellates, and found that four of the five diatom species were sticky and neither flagellate species was. Vast differences in TEP production have been reported in $T$. weissflogii cultures, ranging from little TEP and no observable aggregations of cells (Crocker and Passow, 1995) to copious amounts of TEP (Passow 2002b). Since the phytoplankton cultures used in this experiment were xenic, a possible explanation for these discrepancies is differences in the bacterial consortia associated with the phytoplankton. There is the possibility of synergistic effects with the introduction of new bacteria, which may have triggered TEP production in those bacteria already associated with the phytoplankton or co-aggregation between bacteria as previously observed in biofilms (Rickard et al. 2003; Burmølle et al. 2006). Furthermore, it was not possible to accurately measure the final cell ratio of phytoplankton to bacteria due to aggregate formation. These factors warrant further consideration for better insight into phytoplankton-bacteria aggregation dynamics. Therefore, identifying the bacteria in the phycosphere and understanding their potential interaction in co-cultures could be the basis for future work.

Diverse groups of marine bacteria have been shown to produce significant amounts of exopolymers (Decho 1990;
Costerton et al. 1995; Sugimoto et al. 2007; Decho and Gutierrez 2017). When T. weissflogii and N. oceanica were cocultured with $M$. lutimaris, TEP concentration was at its highest. This is consistent with the observation that marine Bacteroidetes possess 2-3 times more glycosyltransferases (proteins that generate polysaccharides) per mega base pair than Alphaproteobacteria and Gammaproteobacteria, which has been proposed to aid attachment mechanisms via the production of TEP (Fernández-Gómez et al. 2013). Observations of large variations in TEP concentration among phytoplankton-bacteria co-cultures are perhaps not surprising due to the widespread evidence that marine bacteria not only lead to enhanced production of TEP (Costerton et al. 1995; Myklestad 1995; Passow 2002b; Sugimoto et al. 2007) but can also metabolise it (Kiørboe and Hansen 1993; Grossart and Ploug 2001; Kirchman 2002). A widespread characteristic among different marine bacterial groups (Cytophagales, Pseudomonadales and Vibrionales) is their ability to degrade polymers, which may hinder aggregation (Smith et al. 1992; Smith et al. 1995). Ultimately, aggregation will occur when the production of phytoplankton exudates and TEP are favoured over the hydrolytic capacity of the bacteria (Smith et al. 1995).

TEP is certainly implicated in aggregation formation and sinking; therefore, interactions between phytoplankton and bacteria may have profound implications on the biological carbon pump. The dynamic interactions between bacteria and TEP include production, degradation and modification, and these interactions are complex (Passow 2002a). From a biotechnological perspective, applying a bacterium with aggregation capacity in co-culture with phytoplankton is a potentially attractive option for enhancing phytoplankton aggregation, because many bacteria naturally co-exist and thrive in association with phytoplankton. However, the risk of bacterial contamination and the associated costs for bacterial cultivation must also be considered.

Our data indicate that TEP production is only partially responsible for bacteria-mediated phytoplankton aggregation and that other bacterial phenotypes may play a key role. For example, some marine bacteria have specific flagellin genes (Winstanley \& Morgan 1997), and adhesion genes in marine Flavobacteria (Fernández-Gómez et al. 2013) might also play a role in the aggregation of phytoplankton cells. Quorum sensing (QS) has been documented in eukaryotic host-associated gram negative bacteria (Gram et al. 2002; Rolland et al. 2016; Zhou et al. 2017), and mutations in the signalling molecule acyl-homoserine lactone (acyl-HSL) synthase in the bacterium Rhodobacter sphaeroides have led to hyper aggregation of cells in liquid culture (Puskas et al. 1997). A similar QS phenotype was observed in the Gammaproteobacteria, Yersinia pseudotuberculosis where expression of a surface protein with homology to flagellin was thought to mediate aggregation (Atkinson et al. 1999). This evidence highlights that cell signalling may be crucial to the aggregation phenotype in 
bacteria, but there remains a lack of mechanistic understanding of the molecular markers contributing to aggregate formation.

In conclusion, our results indicate that TEP production is an important factor contributing to aggregation efficiency in the marine phytoplankton $T$. weissflogii and $N$. oceanica. The presence of bacteria is an important contributor to aggregation efficiency and TEP production. The large variations observed among even closely related taxonomic groups highlight the inherent complexities of species-specific interactions and strainspecific differences in aggregation efficiency were clear. In general, however, bacteria in the order Rhodobacterales, Flavobacteriales and Sphingomonadales caused the highest levels of aggregation, which also often coincided with the greatest amount of TEP production. We point out that TEP production is just one, of potentially many, mechanism that influence the aggregation of phytoplankton, and future experiments using omics techniques to elucidate other phenotypes and mechanisms involved in bacteria-mediated phytoplankton aggregation will be valuable. However, our results demonstrate both the ubiquity and diversity of bacterial-mediated aggregation of phytoplankton, providing further support to the concept that this form of phytoplankton-bacteria interaction might have widespread importance within both the context of ocean carbon flux and as a means to enhance the efficiency of harvesting of phytoplankton biomass for biotechnological purposes.

Acknowledgements The authors would like to thank Dr. Katherina Petrou for supplying Thalassiosira weissflogii, Dr. Marco Giardina and Dr. Richard Carney for their bacterial isolates and Dr. Matthias S. Ullrich for Marinobacter adhaerens HP15 WT.

Author's contributions Nhan-An T. Tran, Bojan Tamburic and Justin R. Seymour contributed to the study conception and design. Material preparation, data collection and analysis were performed by Nhan-An T. Tran, Bojan Tamburic and Christian R. Evenhuis. The first draft of the manuscript was written by Nhan-An T. Tran and all authors commented on previous versions of the manuscript. All authors read and approved the final manuscript.

Funding This study was funded by an Australian Graduate Research Training Program Scholarship and the University of Technology Sydney Climate Change Cluster (C3) and supported by an Australian Research Council Discovery Grant DP180100838 to J.R. Seymour.

Data availability The datasets generated and analysed during the current study are available as Supplementary Material.

\section{Compliance with ethical standards}

Conflict of interest The authors declare that they have no conflict of interest.

Open Access This article is licensed under a Creative Commons Attribution 4.0 International License, which permits use, sharing, adaptation, distribution and reproduction in any medium or format, as long as you give appropriate credit to the original author(s) and the source, provide a link to the Creative Commons licence, and indicate if changes were made. The images or other third party material in this article are included in the article's Creative Commons licence, unless indicated otherwise in a credit line to the material. If material is not included in the article's Creative Commons licence and your intended use is not permitted by statutory regulation or exceeds the permitted use, you will need to obtain permission directly from the copyright holder. To view a copy of this licence, visit http://creativecommons.org/licenses/by/4.0/.

\section{References}

Alldredge AL, Gotschalk CC (1989) Direct observations of the mass flocculation of diatom blooms: characteristics, settling velocities and formation of diatom aggregates. Deep Sea Res Part A 36:159 171

Alldredge AL, Gotschalk C, Passow U, Riebesell U (1995) Mass aggregation of diatom blooms: insights from a mesocosm study. DeepSea Res Part II 42:9-27

Amin SA, Parker MS, Armbrust EV (2012) Interactions between diatoms and bacteria. Microbiol Mol Biol Rev 76:667-684

Amin SA, Hmelo LR, van Tol HM, Durham BP, Carlson LT, Heal KR, Morales RL, Berthiaume CT, Parker MS, Djunaedi B, Ingalls AE, Parsek MR, Moran MA, Armbrust EV (2015) Interaction and signalling between a cosmopolitan phytoplankton and associated bacteria. Nature 522:98-101

Armbrust EV (2009) The life of diatoms in the world's oceans. Nature 459:185-192

Ashtaputre AA, Shah AK (1995) Studies on a viscous, gel-forming exopolysaccharide from Sphingomonas paucimobilis Gs1. Appl Env Microbiol 61:1159-1162

Atkinson S, Throup JP, Stewart GSAB, Williams P (1999) A hierarchical quorum-sensing system in Yersinia pseudotuberculosis is involved in the regulation of motility and clumping. Mol Microbiol 33:12671277

Bidle KD, Azam F (2001) Bacterial control of silicon regeneration from diatom detritus: significance of bacterial ectohydrolases and species identity. Limnol Oceanogr 46:1606-1623

Buchan A, LeCleir GR, Gulvik CA, Gonzalez JM (2014) Master recyclers: features and functions of bacteria associated with phytoplankton blooms. Nat Rev Microbiol 12:686-698

Burmølle M, Webb JS, Rao D, Hansen LH, Sørensen SJ, Kjelleberg S (2006) Enhanced biofilm formation and increased resistance to antimicrobial agents and bacterial invasion are caused by synergistic interactions in multispecies biofilms. Appl Environ Microbiol 72: 3916-3923

Chiu SY, Kao CY, Tsai MT, Ong SC, Chen CH, Lin CS (2009) Lipid accumulation and $\mathrm{CO}_{2}$ utilization of Nannochloropsis oculata in response to $\mathrm{CO}_{2}$ aeration. Bioresour Technol 100:833-838

Cole JJ (1982) Interactions between bacteria and algae in aquatic ecosystems. Annu Rev Ecol Systemat 13:291-314

Costerton JW, Lewandowski Z, Caldwell DE, Korber DR, Lappin-Scott HM (1995) Microbial biofilms. Annu Rev Microbiol 49:711-745

Cydzik-Kwiatkowska A (2015) Bacterial structure of aerobic granules is determined by aeration mode and nitrogen load in the reactor cycle. Bioresour Technol 181:312-320

de Godos I, Guzman HO, Soto R, Garcia-Encina PA, Becares E, Munoz R, Vargas VA (2011) Coagulation/flocculation-based removal of algal-bacterial biomass from piggery wastewater treatment. Bioresour Technol 102:923-927

Decho AW (1990) Microbial exopolymer secretions in ocean environments: their role(s) in food webs and marine processes. Oceanogr Mar Biol Annu Rev 28:73-153 
Decho AW, Gutierrez T (2017) Microbial extracellular polymeric substances (EPSs) in ocean systems. Front Microbiol 8:00922

Durham BP, Sharma S, Luo H, Smith CB, Amin SA, Bender SJ, Dearth SP, Van Mooy BAS, Campagna SR, Kujawinski EB, Armbrust EV, Moran MA (2015) Cryptic carbon and sulfur cycling between surface ocean plankton. Proc Nat Acad Sci 112:453-457

Engel A (2004) Distribution of transparent exopolymer particles (TEP) in the northeast Atlantic Ocean and their potential significance for aggregation processes. Deep-Sea Res Part I 51:83-92

Engel A, Passow U (2001) Carbon and nitrogen content of transparent exopolymer particles (TEP) in relation to their Alcian Blue adsorption. Mar Ecol Prog Ser 219:1-10

Fernández-Gómez B, Richter M, Schüler M, Pinhassi J, Acinas SG, Gonzalez JM, Predros-Alio C (2013) Ecology of marine Bacteroidetes: a comparative genomics approach. ISME J 7:10261037

Gärdes A, Kaeppel E, Shehzad A, Seebah S, Teeling H, Yarza P, Glöckner FO, Grossart HP, Ullrich MS (2010) Complete genome sequence of Marinobacter adhaerens type strain (HP15), a diatominteracting marine microorganism. Stand Genomic Sci 3:97-107

Gärdes A, Iversen MH, Grossart H-P, Passow U, Ullrich MS (2011) Diatom-associated bacteria are required for aggregation of Thalassiosira weissflogii. ISME J 5:436-445

Geng H, Belas R (2010) Molecular mechanisms underlying roseobacterphytoplankton symbioses. Curr Opin Biotechnol 21:332-338

Goecke F, Thiel V, Wiese J, Labes A, Imhoff JF (2013) Algae as an important environment for bacteria-phylogenetic relationships among new bacterial species isolated from algae. Phycologia 52: $14-24$

Gram L, Grossart HP, Schlingloff A, Kiørboe T (2002) Possible quorum sensing in marine snow bacteria: production of acylated homoserine lactones by Roseobacter strains isolated from marine snow. Appl Environ Microbiol 68:4111-4116

Grossart HP (1999) Interactions between marine bacteria and axenic diatoms (Cylindrotheca fusiformis, Nitzschia laevis, and Thalassiosira weissflogii) incubated under various conditions in the lab. Aquat Microbl Ecol 19:1-11

Grossart HP, Ploug H (2001) Microbial degradation of organic carbon and nitrogen on diatom aggregates. Limnol Oceanogr 46:267-277

Grossart HP, Simon M (2007) Interactions of planktonic algae and bacteria: Effects on algal growth and organic matter dynamics. Aquat Microb Ecol 47:163-176

Grossart HP, Czub G, Simon M (2006a) Algae-bacteria interactions and their effects on aggregation and organic matter flux in the sea. Env Microbiol 8:1074-1084

Grossart HP, Kiørboe T, Tang KW, Allgaier M, Yam EM, Ploug H (2006b) Interactions between marine snow and heterotrophic bacteria: aggregate formation and microbial dynamics. Aquat Microb Ecol 42:19-26

Guillard R, Ryther J (1962) Studies of marine planktonic diatoms I. Cyclotella nana Hustedt, and Detonulla confervacea (Cleve) Gran. Can J Microbiol 8:229-239

Heissenberger A, Herndl GJ (1994) Formation of high molecular weight material by free-living marine bacteria. Mar Ecol Prog Ser 111:129 135

Kaeppel EC, Gärdes A, Seebah S, Grossart H-P, Ullrich MS (2012) Marinobacter adhaerens sp. nov., isolated from marine aggregates formed with the diatom Thalassiosira weissflogii. Int J Syst Evol Microbiol 62:124-128

Kiørboe T, Hansen JLS (1993) Phytoplankton aggregate formation: observations of patterns and mechanisms of cell sticking and the significance of exopolymeric material. J Plankton Res 15:993-1018

Kirchman DL (2002) The ecology of Cytophaga-Flavobacteria in aquatic environments. FEMS Microbiol Ecol 39:91-100
Kranck K, Milligan TG (1988) Macroflocs from diatoms: in situ photography of particles in Bedford Basin, Nova Scotia. Mar Ecol Prog Ser 44:183-189

Krohn-Molt I, Wemheuer B, Alawi M, Poehlein A, Güllert S, Schmeisser C, Pommerening-Röser A, Grundhoff A, Daniel R, Hanelt D, Streit WR (2013) Metagenome survey of a multispecies and algaassociated biofilm revealed key elements of bacterial-algal interactions in photobioreactors. Appl Environ Microbiol 79:6196-6206

Landa M, Blain S, Christaki U (2016) Shifts in bacterial community composition associated with increased carbon cycling in a mosaic of phytoplankton blooms. ISME J 10:39-50

Lee S, Kato J, Takiguchi N, Kuroda A, Ikeda T, Mitsutani A, Ohtake H (2000) Involvement of an extracellular protease in algicidal activity of the marine bacterium Pseudoalteromonas sp. strain A28. Appl Environ Microbiol 66:4334-4339

Li H, Xing P, Chen M, Bian Y, Wu QL (2011) Short-term bacterial community composition dynamics in response to accumulation and breakdown of Microcystis blooms. Water Res 45:1702-1710

Louati I, Pascault N, Debroas D, Bernard C, J-f H, Leloup J (2015) Structural diversity of bacterial communities associated with bloom-forming freshwater cyanobacteria differs according to the cyanobacterial genus. PLoS One 11:e0146866

Mari X, Passow U, Migon C, Burd A, Legendre L (2017) Transparent exopolymer particles: effects on carbon cycling in the ocean. Progr Oceanog 151:13-37

Mayali X, Azam F (2004) Algicidal bacteria in the sea and their impact on algal blooms. J Eukaryotic Microbiol 51:139-144

Milici M, Vital M, Tomasch J, Badewien TH, Giebel H-A, Plumeier I, Wang H, Pieper DH, Wagner-Döbler I, Simon M (2017) Diversity and community composition of particle-associated and free-living bacteria in mesopelagic and bathypelagic Southern Ocean water masses: evidence of dispersal limitation in the Bransfield Strait. Limnol Oceanogr 62:1080-1095

Milledge JJ, Heaven S (2013) A review of the harvesting of micro-algae for biofuel production. Rev Env Sci Biotech 12:165-178

Myklestad SM (1995) Release of extracellular products by phytoplankton with special emphasis on polysaccharides. Sci Total Environ 165:155-164

Neal AL, Dublin SN, Taylor J, Bayes DJ, Burns JL, Apkarian R, DiChristina TJ (2007) Terminal electron acceptors influence the quantity and chemical composition of capsular exopolymers produced by anaerobically growing Shewanella spp. Biomacromolecules 8:166-174

Neef A, Witzenberger R, Kämpfer P (1999) Detection of sphingomonads and in situ identification in activated sludge using 16S rRNA-targeted oligonucleotide probes. J Indust Microbiol Biotechnol 23:261-267

Niederdorfer R, Peter H, Battin TJ (2016) Attached biofilms and suspended aggregates are distinct microbial lifestyles emanating from differing hydraulics. Nature Microbiol 1:16178

Nontembiso P, Sekelwa C, Leonard MV, Anthony OI (2011) Assessment of bioflocculant production by Bacillus sp. Gilbert, a marine bacterium isolated from the bottom sediment of Algoa Bay. Mar Drugs 9:1232-1242

Passow U (2002a) Transparent exopolymer particles (TEP) in aquatic environments. Progr Oceanogr 55:287-333

Passow U (2002b) Production of transparent exopolymer particles (TEP) by phyto- and bacterioplankton. Mar Ecol Prog Ser 236:1-12

Passow U, Alldredge AL (1994) Distribution, size and bacterial colonization of transparent exopolymer particles (TEP) in the ocean. Mar Ecol Prog Ser 113:185-198

Passow U, Alldredge AL (1995) A dye-binding assay for the spectrophotometric measurement of transparent exopolymer particles (TEP). Limnol Oceanogr 40:1326-1335

Powell RJ, Hill RT (2013) Rapid aggregation of biofuel-producing algae by the bacterium Bacillus sp. strain RP1137. Appl Environ Microbiol 79:6093-60101

Powell RJ, Hill RT (2014) Mechanism of algal aggregation by Bacillus sp. strain RP1137. Appl Environ Microbiol 80:4042-4050 
Puskas A, Greenberg EP, Kaplan S, Schaefer AMYL (1997) A quorumsensing system in the free-living photosynthetic bacterium Rhodobacter sphaeroides. J Bacteriol 179:7530-7537

Ramanan R, Kang Z, Kim BH, Choo DH, Jin L, Oh H-M, Kim H-S (2015) Phycosphere bacterial diversity in green algae reveals an apparent similarity across habitats. Algal Res 8:140-144

Rickard AH, Gilbert P, High NJ, Kolenbrander PE, Handley PS (2003) Bacterial coaggregation: an integral process in the development of multi-species biofilms. Trends Microbiol 11:94-100

Riebesell U (1991) Particle aggregation during a diatom bloom. II. Biological aspects. Mar Ecol Prog Ser 69:281-291

Rodolfi L, Zittelli GC, Barsanti L, Rosati C, Tredeci MR (2003) Growth medium recycling in Nannochloropsis sp. mass culture. Biomol Eng 20:243-248

Rolland JL, Stien D, Sanchez-Ferandin S, Lami R (2016) Quorum sensing and quorum quenching in the phycosphere of phytoplankton: a case of chemical interactions in ecology. J Chem Ecol 42:1201-1211

Sañudo-Wilhelmy SA, Gómez-Consarnau L, Suffridge C, Webb EA (2014) The role of B vitamins in marine biogeochemistry. Annu Rev Mar Sci 6:339-367

Sapp M, Schwaderer AS, Wiltshire KH, Hoppe H-G, Gerdts G, Wichels A (2007) Species-specific bacterial communities in the phycosphere of microalgae? Microb Ecol 53:683-699

Schäfer H, Abbas B, Witte H, Muyzer G (2002) Genetic diversity of 'satellite' bacteria present in cultures of marine diatoms. FEMS Microbiol Ecol 42:25-35

Seyedsayamdost MR, Case RJ, Kolter R, Clardy J (2011) The Jekyll-andHyde chemistry of Phaeobacter gallaeciensis. Nature Chem 3:331-335

Simon M, Grossart HP, Schweitzer B, Ploug H (2002) Microbial ecology of organic aggregates in aquatic ecosystems. Aquat Microb Ecol 28: $175-211$

Smetacek VS (1985) Role of sinking in diatom life-hystory: ecological, evolutionary and geological significance. Mar Biol 84:239-251

Smith DC, Simon M, Alldredge AL, Azam F (1992) Intense hydrolytic enzyme activity on marine aggregates and implications for rapid particle dissolution. Nature 359:139-142

Smith DC, Steward GF, Long RA, Azam F (1995) Bacterial mediation of carbon fluxes during a diatom bloom in a mesocosm. Deep-Sea Res Part II 42:75-97

Sonnenschein EC, Syit DA, Grossart HP, Ullrich MS (2012) Chemotaxis of Marinobacter adhaerens and its impact on attachment to the diatom Thalassiosira weissflogii. Appl Environ Microbiol 78:6900-6907

Sugimoto K, Fukuda H, Baki MA, Koike I (2007) Bacterial contributions to formation of transparent exopolymer particles (TEP) and seasonal trends in coastal waters of Sagami Bay, Japan. Aquat Microb Ecol $46: 31-41$
Sukenik A, Shelef G (1984) Algal autoflocculation-verification and proposed mechanism. Biotechnol Bioeng 26:4-9

Teeling H, Fuchs BM, Becher D, Klockow C, Gardebrecht A, Bennke CM, Kassabgy M, Huang S, Mann AJ, Waldmann J, Weber M, Klindworth A, Otto A, Lange J, Bernhardt J, Reinsch C, Hecker M, Peplies J, Bockelmann FD, Callies U, Gerdts G, Wichels A, Wiltshire KH, Glöckner FO, Schweder T, Amann R (2012) Substrate-controlled succession of marine bacterioplankton populations induced by a phytoplankton bloom. Science 336:608-611

Tran N-AT, Seymour JR, Siboni N, Evenhuis CR, Tamburic B (2017) Photosynthetic carbon uptake induces autoflocculation of the marine microalga Nannochloropsis oculata. Algal Res 26:302-311

Ummalyma SB, Gnansounou E, Sukumaran RK, Sindhu R, Pandey A, Sahoo D (2017) Bioflocculation: an alternative strategy for harvesting of microalgae-an overview. Bioresour Technol 242:227-235

Vandamme D, Foubert I, Fraeye I, Meesschaert B, Muylaert K (2012) Flocculation of Chlorella vulgaris induced by high $\mathrm{pH}$ : Role of magnesium and calcium and practical implications. Bioresour Technol 105:114-119

Vandamme D, Foubert I, Muylaert K (2013) Flocculation as a low-cost method for harvesting microalgae for bulk biomass production. Trends Biotech 31:233-239

Wan C, Zhao X-Q, Guo SL, Alam MA, Bai F-W (2013) Bioflocculant production from Solibacillus silvestris W01 and its application in cost-effective harvest of marine microalga Nannochloropsis oceanica by flocculation. Bioresour Technol 135:207-212

Wang H, Laughinghouse HD 4th, Anderson MA, Chen F, Willliams E, Place AR, Zmora O, Zohar Y, Zheng T, Hill RT (2012) Novel bacterial isolate from permian groundwater, capable of aggregating potential biofuel-producing microalga Nannochloropsis oceanica IMET1. Appl Environ Microbiol 78:1445-1453

Yamazaki M, Thorne L, Mikolajczak M, Armentrout RW, Pollock TJ (1996) Linkage of genes essential for synthesis of a polysaccharide capsule in Sphingomonas strain S88. J Bacteriol 178:2676-2687

Zheng H, Gao Z, Yin J, Tang X, Ji X, Huang H (2012) Harvesting of microalgae by flocculation with poly ( $\gamma$-glutamic acid). Bioresour Technol 112:212-220

Zhou D, Zhang C, Fu L, Xu L, Cui X, Li Q, Crittenden JC (2017) Responses of the microalga Chlorophyta sp. to bacterial quorum sensing molecules ( $\mathrm{N}$-acylhomoserine lactones): aromatic proteininduced self-aggregation. Env Sci Technol 51:3490-3498

Publisher's note Springer Nature remains neutral with regard to jurisdictional claims in published maps and institutional affiliations. 